\title{
Intestinal Protozoa Infections in Relation to Nutritional Status of the Mandangin Island Elementary School 6 Students in Sampang Regency
}

\author{
Marlinda Kurniati $^{1}$, Budiono ${ }^{2^{*}}$, Sri Wijayanti Sulistyawati ${ }^{3}$
}

\author{
${ }^{1}$ Faculty of Medicine, Universitas Airlangga, Surabaya. \\ 2 Department of Public Health and Preventive Medicine, Faculty of Medicine, Universitas Airlangga, Surabaya. \\ ${ }^{3}$ Department of Parasitology, Faculty of Medicine, Universitas Airlangga, Surabaya.
}

\section{A B S T R A C T}

Introduction: Intestinal protozoa infections is a tropical infectious disease that can be found mainly in developing countries. It will cause some health problem such as undernutrition and stunting. This study was aiming to determine the correlation between the prevalence of intestinal protozoa infections with the nutritional status of Mandangin Island Elementary School 6 students in Sampang Regency.

Methods: The cross-sectional study was used as the design in this research. The prevalence of protozoa intestinal infections was performed by doing a stool examination on a light microscope. Meanwhile, the nutritional status was calculated using BMI-for-ageand height-for-ageindex, recruited from Mandangin Island Elementary School 6 students. Both variables were analysed using SPSS.

Results: On microscopic examination has found $71.4 \%(\mathrm{n}=30)$ positive samples and $28,6 \%(n=12)$ negative samples. On BMI-for-age measurement there were $4,8 \%$ obesity, $7,1 \%$ overweight, $73,8 \%$ normal, $9,5 \%$ thinness, and $4,8 \%$ severe thinness. Meanwhile, on height-for-age measurement there ware $73,8 \%$ normal and $26,2 \%$ stunted. The prevalence of intestinal protozoa infections was correlated with the nutritional status using SPSS $(p=0,375, p=0,539, a=5 \%)$.

Conclusion: There was no significant correlation between intestinal protozoa infections with the nutritional status of Mandangin Island Elementary School 6 students in Sampang Regency. These conditions caused by the pathogenicity stage to cause a decrease in the nutritional state has not been reached.

\section{*Correspondence: budiono@fk.unair.ac.id}

JUXTA: Jurnal IImiah Mahasiswa Kedokteran Universitas Airlangga

p-ISSN: 1907-3623; e-ISSN: 2684-9453

DOI: $10.20473 /$ juxta.V10I12019.25-28

Open access under Creative Commons Attribution-ShareAlike 4.0 International License (CC-BY-SA)

\section{ARTICLE INFO}

Article history:

Received 4 December 2018

Received in revised form 22 January 2019

Accepted 23 December 2019

\section{Keywords:}

Intestinal protozoa infections, Nutritional status,

Blastocystis hominis, Giardia lamblia. 


\section{Introduction}

Undernutrition and stunting are one of many kind health problems that found in developing countries, including Indonesia. This condition usually was associated with helminth and other chronic infections. If we see it holistically, undernutrition and stunting can also cause by bacterial infections and intestinal protozoa infections.

Intestinal protozoa infections is a tropical infectious disease that mainly can be found in developing countries. A study in West Sumba shows $95.5 \%$ of all samples were infected by Intestinal Parasitic Infections ${ }^{1}$. Protozoa infections can occur in the intestine or other organs according to their life cycle. The protozoa that commonly found as intestinal protozoa infections include Blastocystishominis, Entamoebahistolytica, Giardia lamblia, Balantidiumcoli, and Cryptosporidium sp. Intestinal protozoa infections can be found as single-infection or mixinfection ${ }^{2}$. Infections caused by intestinal protozoa from different species will cause different symptoms but also have common symptoms such as weight loss ${ }^{3}$.

Intestinal protozoa infections mainly found in elementary school age children. This is because of their knowledge about personal hygiene and healthy life behaviors are still improving ${ }^{4}$. Infections caused by intestinal protozoa will lead to physiological changes which over a long time will reduce the host's nutritional status ${ }^{5}$.

Intestinal protozoa infections usually occur in areas with poor sanitation status, low economic status, inadequate water sources and health facilities. These characteristics representeted by the general condition of Mandangin Island, Sampang District, Sampang Regency.

Based on the background, This study was aiming to determine "Intestinal Protozoa Infections in Relation to Nutritional Status of the Mandangin Island Elementary School 6 in Sampang Regency" to find out the correlation between the two variables.

\section{Methods}

This research was a cross-sectional study. The research variables were the prevalence of intestinal protozoa infections and nutritional status of the students. This research had received approval of ethical clearance from ethics commission of Faculty of Medicine Universitas Airlangga Surabaya.

Stool samples were obtained using random sampling technique according to inclusion criterias which were the samples collected from $2^{\text {nd }}-6^{\text {th }}$ grade student of Mandangin Island Elementary School 6 . The stool samples were examined using direct smear method. For the statistical analysis there were any consideration such as the samples must be equipped by identity, questionnaire, measurement of height and weight, and the results of the microscopic examination, especially for the positive samples, were included in the 5 species that studied in this study (E. histolytica, G. lamblia, B. hominis, B. coli, and Cryptosporidium sp).

Initially the prevalence of intestinal protozoa infections, nutritional status measurements, and associated factors were assessed descriptively by using Microsoft Excel 2010. Risk factors were identified using chi-square test. Then, the correlation between the prevalence of intestinal protozoa infections with the nutritional status was determined by chisquare test. $P$ values less than 0.05 were considered statistically significant. SPSS software (Statistical Package for the Social Sciences) for windows version 16 was used for statistical analysis.

\section{Results}

\section{Prevalence of Intestinal Protozoa Infections}

The study included 42 elementary school students, consisted of 21 males (50.0\%) and 21 females (50.0\%). The age was ranging between 6 and 15 years old, which were categorized into two age groups (Table 2). About $71.4 \%$ (30) of the participants were infected by intestinal protozoa. B.hominiswas the most prevalent species $(40.5 \%$; 17) followed by G.lamblia which prevalence rates was $19.0 \%$ (8) (Table 1). For the $2^{\text {nd }}$ table, the number of the samples (n) can be $<47$ due to missing values. Both single infection of $B$. hominis and $G$. lamblia added with 5 mix infection.

Table 1.Distribution of Intestinal Protozoa Infections by species

\begin{tabular}{lcc}
\hline \multicolumn{1}{c}{ Protozoa Infections } & $\mathbf{n}$ & $\%$ \\
\hline $\begin{array}{l}\text { Single Infection } \\
\quad \text { Blastocystis hominis } \\
\quad \text { Giardia lamblia }\end{array}$ & 17 & 40,5 \\
$\begin{array}{l}\text { Mix Infection } \\
\quad \text { Blastocystis hominisand } \\
\quad \text { Giardia lamblia }\end{array}$ & 8 & 19,0 \\
$\quad$ Negative & 5 & 11,9 \\
\hline TOTAL & 12 & 28,6 \\
\hline Source: Research Data, Processed & $\mathbf{4 2}$ & $\mathbf{1 0 0}$ \\
\hline
\end{tabular}

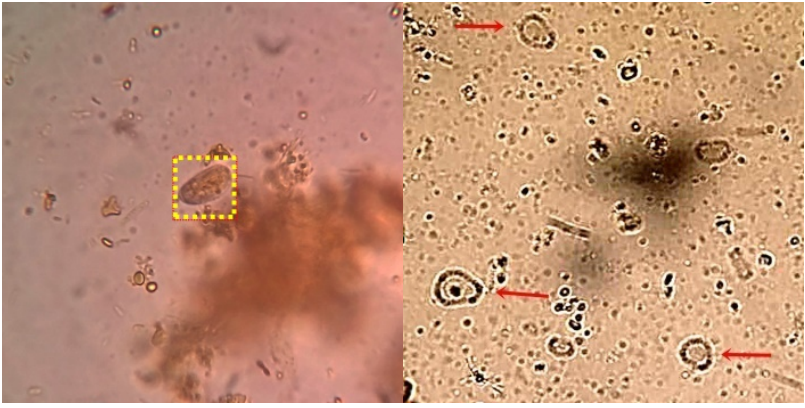

(A)

(B)

Figure 1. On light microscopic examination has found Giardia lambia cysts $(A)$ and vacuolar form of Blastocystis hominis $(\mathrm{B})$

Table 2.Prevalence of Intestinal Protozoa Infections by age and gender

\begin{tabular}{cccc}
$n$ & $\begin{array}{c}\text { Negative } \\
(\%, \mathrm{n})\end{array}$ & $\begin{array}{c}\text { Blastocystis } \\
\text { hominis }(\%, \mathrm{n})\end{array}$ & Giardia \\
\hline
\end{tabular}




\begin{tabular}{lllll}
\hline & & & & $\begin{array}{c}\text { Iamblia }(\%, \\
\mathbf{n})\end{array}$ \\
\hline Gender & & & & $12,8(6)$ \\
Male & 23 & $12,8(6)$ & $23,4(11)$ & $14,9(7)$ \\
Female & 24 & $12,8(6)$ & $23,4(11)$ & $19,1(9)$ \\
\hline Age & & & & $8,5(4)$ \\
$\leq 10$ & 29 & $12,8(6)$ & $29,8(14)$ & \\
years & 18 & $12,8(6)$ & $17,0(8)$ & \\
$>10$ & & & & \\
years & \multicolumn{5}{l}{} \\
Source: Research Data, Processed
\end{tabular}

\section{Intestinal Protozoa Infections and risk factor}

Risk factors associated with intestinal protozoa infections in relation to personal hygiene, self habit, and environmental sanitation were assessed by chi square test. The data on risk factors are summarized in $3^{\text {rd }}$ table. And it showed no significant correlation with the intestinal protozoa infections $(p>0.05)$. As a note, the number of the samples ( $\mathrm{n}$ ) can be $<47$ due to missing values. Both single infection of $B$. hominis and $G$. lamblia added with 5 mix infection.

Table 3.Associated risk factors

\begin{tabular}{|c|c|c|c|c|}
\hline & $\mathbf{N}$ & $\begin{array}{c}\text { Negative } \\
(\%, n)\end{array}$ & $\begin{array}{c}\text { Positive } \\
(\%, \mathrm{n})\end{array}$ & $P$-value \\
\hline $\begin{array}{l}\text { Hand washing } \\
\text { before eating } \\
\text { Yes } \\
\text { No }\end{array}$ & $\begin{array}{r}41 \\
3 \\
\end{array}$ & $\begin{array}{l}25,0(11) \\
2,3(1)\end{array}$ & $\begin{array}{l}68,2(30) \\
4,5(2)\end{array}$ & 0,807 \\
\hline $\begin{array}{l}\text { Wash ingredients } \\
\text { before } \\
\text { cooking/eating } \\
\text { Yes } \\
\text { No }\end{array}$ & $\begin{array}{r}42 \\
4\end{array}$ & $\begin{array}{l}23,9(11) \\
2,2(1)\end{array}$ & $\begin{array}{l}67,4(31) \\
6,5(3)\end{array}$ & 0,959 \\
\hline $\begin{array}{l}\text { Snacking habits } \\
\text { outside } \\
\text { Yes } \\
\text { No }\end{array}$ & $\begin{array}{r}42 \\
3\end{array}$ & $\begin{array}{l}24,4(11) \\
2,2(1)\end{array}$ & $\begin{array}{l}68,9(31) \\
4,4(2)\end{array}$ & 0,787 \\
\hline $\begin{array}{l}\text { Having diarrhea } \\
\text { lately } \\
\text { Yes } \\
\text { No }\end{array}$ & $\begin{array}{l}16 \\
30\end{array}$ & $\begin{array}{l}6,5(3) \\
19,6(9)\end{array}$ & $\begin{array}{l}28,3(13) \\
45,7(21)\end{array}$ & 0,408 \\
\hline $\begin{array}{l}\text { Water source } \\
\text { PDAM } \\
\text { Others }\end{array}$ & $\begin{array}{r}6 \\
41 \\
\end{array}$ & $\begin{array}{l}2,1(1) \\
23,4(11)\end{array}$ & $\begin{array}{l}10,6(5) \\
63,8(30)\end{array}$ & 0,594 \\
\hline $\begin{array}{l}\text { Playing with cattle } \\
\text { Yes } \\
\text { No }\end{array}$ & $\begin{array}{l}27 \\
19\end{array}$ & $\begin{array}{l}13,0(6) \\
13,0(6)\end{array}$ & $\begin{array}{l}45,7(21) \\
28,3(13)\end{array}$ & 0,477 \\
\hline
\end{tabular}

\section{Intestinal Protozoa Infections and Nutritional Status}

Prevalence of intestinal protozoa infections in relation to food intake status was assessed by chi square test in Table 4. It showed no significant correlation between them $(p>0.05)$. And also there is no correlation between nutritional state and intestinal protozoa infections. As a note, a total of the positive samples on Table 5 obtained from single infection (25) + mix-infection $(5)=30$.

Table 4.Food intake status

\begin{tabular}{lcccc}
\hline & N & $\begin{array}{c}\text { Negative } \\
(\%, \mathbf{n})\end{array}$ & $\begin{array}{c}\text { Positive } \\
(\%, \mathbf{n})\end{array}$ & $P$-value \\
\hline $\begin{array}{l}\text { Eating frequency } \\
<3 \text { times per day }\end{array}$ & 19 & $12,8(6)$ & $25,5(12)$ & 0,334 \\
$\geq 3$ times per day & 28 & $12,8(6)$ & $48,9(23)$ & \\
\hline Healthy four & & & & \\
perfectly five & & & & 0,668 \\
Yes & 21 & $12,8(6)$ & $31,9(15)$ & \\
No & 26 & $12,8(6)$ & $42,6(20)$ & \\
\hline
\end{tabular}

Source: Research Data, Processed
Table 5.Nutritional State based on Intestinal

\begin{tabular}{lllll} 
& & & \\
& $\begin{array}{c}\text { Positive } \\
(\%, n)\end{array}$ & $\begin{array}{c}\text { Negative } \\
(\%, n)\end{array}$ & $\begin{array}{c}\text { Total } \\
(\%, n)\end{array}$ & $P$-value \\
$\begin{array}{l}\text { IPItritional } \\
\text { State index }\end{array}$ & & & & \\
\hline Height for age & & & & \\
Stunting & $21,4(9)$ & $4,6(2)$ & 26,2 & \\
Normal & $50,0(21)$ & $23,8(10)$ & $(11)$ & 0,375 \\
& & & 73,8 & \\
& & & $(31)$ & \\
\hline BMI for age & & & & \\
Severe thinness & $2,4(1)$ & $2,4(1)$ & $4,8(2)$ & \\
Thinness & $4,8(2)$ & $4,8(2)$ & $9,6(4)$ & \\
Normal & $54,8(23)$ & $19,0(8)$ & 73,8 & 0,539 \\
Overweight & $7,1(3)$ & $0(0)$ & $(31)$ & \\
Obesity & $2,4(1)$ & $2,4(1)$ & $7,1(3)$ & \\
& & & $4,8(2)$ & \\
\hline
\end{tabular}

Source: Research Data, Processed

\section{Discussion}

On microscopic examination, $B$. hominis is the most frequent, followed by $G$. lamblia and Blasto-Giardia mixed infection. In a study conducted by Sungkar on Sumba, $B$. hominis infection was $34.4 \%$ and Giardia lamblia $4.5 \%{ }^{1}$. And a study on Samosir Island which received $23.1 \%$ positive samples of protozoa with $4.9 \%$ B.hominis infection and G. lamblia at $12.2 \%$. It can be concluded that the prevalence of B.hominis on Mandangin Island is higher than in other regions. $B$. hominis and G.lamblia infection in boys and girls have the same prevalence. Meanwhile, based on the age both of them are found in children less than 10 years.

On the results of the questionnaire variable analysis with the prevalence of intestinal protozoa infection, there was no significant correlation in personal hygiene, habits, sanitation aspects. It caused by several things such as the small number of samples, the questionnaire questions are not answered completely, and the students have difficulty in understanding the contents of the question constrained by language problems. Although there was no significant relationship between them, based on an analysis of the numbers obtained, the majority of these children had snack habits outside where it had a high chance of being contaminated by various microorganisms including protozoan intestinal cysts. In addition, they also have the habit of playing with the cattle, and well is their mainwater sources.A study conducted in Bali shows that a high number of open defecation has a significant correlation in Blastocystis spp. Infection ${ }^{7}$. Meanwhile in Mojo, parent's knowledge about diarrhea and behavior of washing hands after playing have a significant correlation in intestinal parasite infection ${ }^{9}$.

Based on table 4, mostly they eat $\geq 3$ times per day, but the foods were not meet the healthy four perfectly five criteria. The frequency of eating and the diversity of food is calculated as the intake status, where the amount of intake with energy use must be balanced to get a normal nutritional status. Sachithananthan in his study proved that eating frequency did not have a significant correlation to 
body mass index in children in Abha City ${ }^{9}$. In addition, a study conducted by Christina concluded that consuming a variety of foods has a relationship to nutritional status in children ${ }^{10}$.

Theoretically, intestinal protozoa infections have a correlation with nutritional status, this can be intestinal protozoa infections that cause changes in nutritional status, or nutritional status, especially a decrease in nutritional status can affect the host's immune system so that it is more easily infected by pathogenic organisms ${ }^{11}$. In the analysis, for the prevalence of mixed intestinal protozoa infection of $B$. hominis-G. lamblia was included in the category of single infection by $G$. lamblia based on the statement that $B$. hominis could be pathogenic if at least 5 organisms were observed from the whole field of view using 400 times magnification and no other parasitic infections ${ }^{12}$.

Based on table 5, it describes the correlation of intestinal protozoa infections and overall nutritional status statistically. It showed that there was no significant correlation. There are several theories that can underline this situation. First the high frequency and quality of food consumption will increase the food intake status, so even though the energy use was high, it will be compensated by the food intake status, at least the nutritional status will be in the normal-obesity range ${ }^{3}$. Secondly, for the positive samples, especially positive infected by $B$. hominis, it can be caused by the low level of pathogenicity.

For the nutritional status based on the height-for-age index of 42 students found that $73,8 \%$ were normal and $26,2 \%$ stunted. Epidemiologically, the percentage of stunted is still high. On Nutritional Status Observationin 2017 based on the height-for-age index, showed the prevalence of stunted in Indonesia was $19,8 \%$. In NTT, anendemic area of malaria infections showed the prevalence of stunted was $22,3 \%$ and the lowest in Bali was $14,7 \%{ }^{13}$. It can be concluded thatthe prevalence of stunted in Mandangin Island is higher than NTT and Bali. Stunted represents chronic undernutrition that can be lead to growth disturbance in children.

\section{Conclusion}

High prevalence of intestinal protozoa infections in Mandangin Island Elementary School 6 students was not followed by a decrease in nutritional status. This situation caused by the degree of pathogenicity that has not reached the limit where it can cause clinical manifestations such as decrease in nutritional status. Meanwhile, a high prevalence of stunting based on the height-for-age indexmay be associated with the lack of varied food consumption over a long period.

\section{CONFLICT OF INTEREST}

The author stated there is no conflict of interest.

\section{REFERENCES}

1. Sungkar S, Pohan APN, Ramadani A, et al. Heavy Burden of Intestinal Parasite Infections in Kalena Rongo Village, a Rural Area in South West Sumba, Eastern Part of Indonesia: a Cross Sectional Study. BMC Public Health. 2015; 15: 1296.

2. Soedarto S. Buku Parasitologi Kedokteran. 2010.

3. Haque R. Human Intestinal Parasites. Journal of Health, Population, and Nutrition. 2007; 25: 387-91.

4. Indonesia KKR. Profil Kesehatan Indonesia. 2016.

5. Rajoo Y, Ambu S, Lim YA, et al. Neglected Intestinal Parasites, Malnutrition and Associated Key Factors: A Population Based Cross-Sectional Study among Indigenous Communities in Sarawak, Malaysia. PloS one. 2017; 12: e0170174.

6. Yulfi H, Masyithah Darlan D, Wandra T, et al. Intestinal Protozoa Infections and Associated Risk Factors in Rural Community of Samosir Island Indonesia. 1st Public Health International Conference (PHICo 2016). Atlantis Press, 2011.

7. Diarthini N. Identifikasi Blastocystis dan Faktor Risiko Blastocystosis pada Anak Sekolah Dasar di Desa Dukuh, Kecamatan Kubu, Kabupaten Karangasem, Bali. 2018.

8. Zein K. Comparison Study of Intestinal Parasite Infection and Risk Factors Among Primary School First and Second Graders in Mojo and Simolawang Village, Surabaya. 2017.

9. Sachithananthan V and Gad N. A Study on the Frequency of Food Consumption and its Relationship to BMI in School Children and Adolescents in Abha City, KSA. 2016, p.2049

10. Nti C. Dietary Diversity is Associated with Nutrient Intakes and Nutritional Status of Children in Ghana. 2011.

11. Katona $P$ and Katona-Apte J. The Interaction between Nutrition and Infection. Clinical infectious diseases : An Official Publication of the Infectious Diseases Society of America. 2008; 46: 1582-8.

12. Indonesia. KKR. Pemantauan Status Gizi dan Indikator Kinerja Gizi. 2017. 